This item is the archived peer-reviewed author-version of:

Peripheral somatosensory stimulation and postural recovery after stroke : a systematic review

\title{
Reference:
}

Schröder Jonas, Truijen Steven, Van Criekinge Tamaya, Saeys Wim.- Peripheral somatosensory stimulation and postural recovery after stroke : a systematic review

Topics in stroke rehabilitation - ISSN 1074-9357 - 25:4(2018), p. 312-320

Full text (Publisher's DOI): https://doi.org/10.1080/10749357.2018.1440694

To cite this reference: https://hdl.handle.net/10067/1491180151162165141 


\section{Peripheral somatosensory stimulation and postural recovery after 2 stroke - a systematic review}

Purpose. It is hypothesized that peripheral somatosensory stimulation (PSS) can promote postural recovery after stroke by increasing afferent input and postural contribution of the paretic leg. Therefore, this systematic review aims to investigate which PSS approaches are documented and investigated on effectiveness.

Methods. Five databases (PubMed, Web of Science, PEDro, Cochrane Library Trials, RehabData) have been searched on clinical studies in stroke rehabilitation, investigating PSS, which is defined as a non-motor and focal stimulation to the paretic leg aiming an increase in somatosensory input.

Results. Twenty studies present different PSS approaches (mainly electrical and vibration stimulation) and following results: (I.) There is an immediate effect after a single session of PSS on postural stability. In contrast, (II.) repetitive sessions of isolated PSS led to highly inconsistent results. Finally, (III.) PSS as an adjuvant to exercises did promote long-term postural recovery. Conclusion. PSS is found to be effective immediately and on a long-term as an adjuvant therapy only in improving postural stability in a chronic stroke population. However, if PSS enhances paretic leg postural contribution remains unclear. Future research is warranted considering promising results and high prevalence of postural instability impacting daily life of stroke survivors.

Keywords: Stroke; Balance; Postural Recovery; Somatosensation; Stimulation; Review 
More than half of stroke survivors become moderately to severely disabled and are unable to walk, with the majority still experiencing severe disability even after the rehabilitation phase ${ }^{1-3}$. Standing balance control is fundamental for the ability to ambulate ${ }^{4}$ and needs to be addressed in postural rehabilitation as soon as possible. Standing balance control is multifactorial, making it difficult for therapists to determine underlying mechanisms and setting rehabilitation goals. In a cohort by Tyson et al. ${ }^{5}$, weakness and somatosensation are found to be most important. Strengthening after stroke is covered in literature ${ }^{6}$ and muscle strength was able to explain only some variability in upright standing performance after stroke ${ }^{7}$. Apparently, other factors predominate. Stroke-related somatosensory impairments are common (50-80\% of stroke survivors $^{8}$ ) and found to be related to balance ${ }^{5,9}$, gait ${ }^{10}$ and activities of daily living ${ }^{8}$. High prevalence and a functional impact on postural stability suggest addressing somatosensation in postural rehabilitation to be of great importance.

In addition, stroke survivors tend to rely heavily on their non-paretic leg during upright standing ${ }^{11,12}$. They seem to be constrained to the non-paretic side in developing adaptive postural strategies. This asymmetric shift of postural contribution is found to be somehow successful in static ${ }^{13}$, but ineffective in dynamic situations, e.g. during gait 14,15. Therefore, novel therapeutic strategies are warranted which take the functional impact of somatosensation and asymmetric postural contribution into account.

A promising intervention might be peripheral somatosensory stimulation (PSS). Firstly, enhancing afferent input, e.g. by the use of electrical stimulation or vibration, might re-weight sensory processing for balance, leading to the re-integration of the affected leg as a somatosensory organ for postural stability. This might decrease visual over-reliance while keeping an upright posture which is commonly observed after 
49 stroke ${ }^{16}$. Secondly, PSS in the form of low-intensity electrical stimulation aiming to

50 activate cutaneous and proprioceptive sensory fibres is found to drive corticomotor

51 excitability ${ }^{17}$ and by that facilitate effects of motor training ${ }^{18,19}$. Similar effects after

52 PSS in postural recovery may firstly promote postural contribution of the paretic leg

53 leading to more symmetric and efficient postural strategies ${ }^{20}$ and secondly improve

54 functional gains of balance training ${ }^{18}$.

55 To examine our hypothesis, a systemic review is conducted to investigate which

56 PSS strategies are already documented and investigated on effectiveness in postural

57 recovery after stroke. Therefore, this review aims to investigate whether PSS to the

58 paretic leg in stroke rehabilitation leads to improved balance ability and the

59 development of symmetric postural strategies compared to no additional or sham

60 stimulation. 


\section{Methods}

62 The current review was conducted following the guidelines of PRISMA (Preferred

63 Reporting Items for Systematic Reviews and Meta-analysis) to guarantee high-quality

64 reporting ${ }^{21}$.

65

66

67

68

69

\section{Eligibility criteria}

\section{Types of studies}

Clinical trials (randomized-controlled trials (RCT) and non-randomized observational trials) with full-text publications in English, German or Dutch have been included. There were no publication date limits. Meta-analyses, reviews and case-reports have been excluded.

\section{Types of participants}

The population is defined as people after stroke. No limits have been set on the type (infarct/haemorrhage), location (anatomical) or stage (acute/chronic) of the lesion. Studies investigating effects on a stroke population suffering from visuospatial neglect are excluded.

\section{Types of interventions}

Stimulation in the current review is defined as a non-motor, peripheral and focal stimulation to the paretic leg aiming an increase in somatosensory input to spinal and supra-spinal levels. Stimulation above motor threshold (e.g. Functional Electrical Stimulation, a stimulation modality aiming to elicit muscle contraction) and stimulation addressing other parts of the body (e.g. non-invasive brain stimulation such as tDCS, a stimulation modality aiming to affect cortical excitability through electrodes attached to the head; or whole-body vibration where patients are standing on a vibrating platform) are excluded. Studies combining exercises with PSS are excluded if the control group did not receive a dose-and-content-matched exercise intervention. 
The outcomes are defined as recovery of static and dynamic postural stability.

\section{Information sources}

Five databases (PubMed, Web of Science, PEDro, Cochrane Library Trials, RehabData) have been searched.

A search strategy in PubMed [see appendix] (on 26/06/2017) led to 900 hits. A similar strategy in Web of Science (on 26/06/2017) resulted in 464 hits. The searchterm combination of "stroke", "stimulation" and "balance" was used in the PEDro database (54), RehabData (24) and Cochrane Library Trials (135) (on 01/07/2017) leading to additional 213 hits. A two-phase selection procedure is performed to detect studies fulfilling inclusion criteria.

\section{Methodological quality}

The risk of bias was evaluated for RCTs with the PEDro scale. Items are rated by two independent and trained reviewers. A score of $8 / 10$ or higher is defined as good (1++) and 6-7/10 as fair quality (1+). A score below 6 is considered poor quality (1-). Nonrandomized studies were rated by two independent reviewers with a rating system based on the Newcastle-Ottawa Scale (NOS). A score of $4 / 6$ or higher is considered fair quality (2+). A score below is considered poor quality (2-). Finally, methodological quality and level of evidence was rated based on a grading system proposed by Harbour et al. ${ }^{22}$ [see Table $1 \& 2$ ].

\section{Analysis}

Data of included studies are extracted into a spreadsheet listing study characteristics and observed effects [see Table 3]. Extraction happened independently and was double checked. 
INSERT TABLE 1 AND 2 HERE 


\section{Results}

\section{Study selection}

114 After screening on title and deduplication, 96 unique studies were obtained for a

115 detailed screening. Eleven additional studies were added by hand screening, derived

116 from previously published literature reviews in this field of research. After screening,

11719 studies have been selected for analysis [see Figure 1].

118 Studies were excluded based on following reasons: Population did not consist of

119 stroke survivors; stroke survivors suffer from visuospatial neglect; stimulation was

120 above motor threshold or not applied to the lower limb; study design was either a

121 review or a case report/series.

\section{Population}

125 A total number of 691 stroke survivors were observed. The majority received sensory-

126 amplitude electrical stimulation (SES) $(\mathrm{N}=479)$. Local vibration ( $\mathrm{N}=91)$, thermal

127 stimulation $(\mathrm{N}=89)$ and hands-on stimulation $(\mathrm{N}=32)$ are less investigated.

128 In the current review (sub-)acute is defined as less than, and chronic more than

129 six months since stroke onset. The majority of included studies investigated effects in a

130 chronic population ${ }^{23-36}$ compared to the acute phase ${ }^{37-41}$.

131 Included studies selected participants on the ability to keep an upright posture or

132 to ambulate, as they had to stand, walk or transfer during the intervention and

133 assessment. Few studies included stroke survivors with ankle spasticity ${ }^{30-32,34,35}$ or foot

134 drop only ${ }^{23}$. 
136 Outcome measures are divided into static and dynamic postural stability. Static postural stability is measured technically via posturography assessing

138 postural sway (defined as center-of-pressure displacement) ${ }^{30,33,35,36}$ or distribution of

139 weight ${ }^{25}$ during upright standing. Clinical assessments include the Berg Balance Scale

140 (BBS) ${ }^{29,38-40}$, the Postural Assessment Scale for Stroke ${ }^{41}$ and the Functional Reach

141 Test $^{27}$.

142 Dynamic postural stability includes outcomes measuring the ability to ambulate

143 and to transfer. Few studies utilized a gait analysis assessing kinematics ${ }^{23,37}$,

144 spatiotemporal characteristics ${ }^{23,24,33,36,37}$ and gait speed $23,26-28,31-33,36,37$. Clinical

145 measures include the Timed Up and Go test (TUG) $32,34,36,40$ the modified Motor

146 Assessment Scale $28,38,39$, the basic mobility section of the Stroke Rehabilitation

147 Assessment of Movement ${ }^{41}$, the Functional Ambulation Classification ${ }^{38,39,41}$ and the 6-

148 Minute Walking Test ${ }^{32,40}$.

\section{Methodological quality}

150 Two out of the 15 included RCTs present good or $1++$ quality ${ }^{23,32}$. Scores of other

151 RCTs vary between $7 / 10^{33,37-40}$ and $6 / 10^{25,27,31,36,41}$ indicating $1+$ quality. Two RCTs

152 present a high risk of bias or 1- quality ${ }^{30,34}$. A single RCT has not yet been rated.

153 Therefore the authors of the current review conducted the rating based on the PEDro

154 scale, leading to a score of $7 / 10$ and $1+$ quality ${ }^{35}$. The NOS scores for non-randomized 155 trials vary from fair $(2+)^{24,28}$ to poor (2-) ${ }^{26,29}$.

\section{PSS approaches, observed effects and level of evidence}

157 Different PSS approaches are identified (SES, vibration, thermal and hands-on 158 stimulation) and grouped according to the following classification: (I.) Immediate 
159 effects after or during a single session of PSS; (II.) effects after repetitive sessions of

160 isolated PSS compared to no stimulation; (III.) effects of PSS combined with exercises

161 compared to a dose-and-content-matched exercise group which got no or sham

162 stimulation.

(I.) Beneficial effects during SES were observed for static postural stability ${ }^{27,30}$

164 compared to sham stimulation. In addition, speed ${ }^{27}$ and locomotor control ${ }^{24}$ of gait

165 improved during SES which is similar to those effects seen during local vibration ${ }^{26}$. A

166 single session of hands-on stimulation, aiming improvements in soft tissue elasticity and

167 somatosensation of the paretic foot, led to an improved static postural stability ${ }^{29}$. All

168 immediate effects are reported in a chronic population based on level B evidence.

169 (II.) Exposing the paretic foot repetitively to a thermal agent led to beneficial

170 effects on dynamic but inconsistent effects on static postural stability in an acute

171 population ${ }^{38,39}$. In addition, effects disappeared at a 6-month follow-up ${ }^{39}$. Hsu et al. ${ }^{41}$

172 found noxious stimulation (heat 46-47C; cold 2-3C) to be superior for regaining

173 dynamic postural stability. Paoloni et al. ${ }^{23}$ investigated isolated local vibration added to

174 usual care and found improved gait. In contrast, repetitive application of isolated SES

175 (e.g. TENS) led to neutral effects on gait ability ${ }^{28,31,32,37}$ and only a small improvement

176 in the TUG compared to no stimulation ${ }^{32}$ according to level A evidence.

177 (III.) Combining SES with exercises (task-oriented training) did improve static,

178 as assed by posturography ${ }^{35,36}$ and the BBS ${ }^{40}$, and dynamic ${ }^{31,32,36,40}$ postural stability

179 compared to a dose-and-content-matched sham-stimulation group. The latter notion

180 includes for example improvements on the TUG ${ }^{32,36,40}$ and in gait speed ${ }^{31,32}$. Effects

181 persisted even at a follow-up measurement as reported by level A evidence ${ }^{31,32,40}$.

182 However, a single RCT with a high risk of bias found no superior effects on the TUG ${ }^{34}$.

183 Performing exercises during local vibration, as well as applying hands-on stimulation as 
184 a part of a sensorimotor therapy protocol, did improve static postural stability according

185 to posturographic measures ${ }^{25,33}$.

186

187

INSERT TABLE 3 HERE 


\section{Discussion}

189 As somatosensory loss impacts rehabilitation after stroke negatively ${ }^{8,42}$, the question

190 arose whether enhancing somatosensory input during rehabilitation by means of PSS

191 promotes postural recovery gains. Different stimulation approaches were grouped

192 leading to the following results: (I.) There is an immediate effect after a single session

193 of PSS on postural stability, in contrast with (II.) repetitive sessions of isolated PSS

194 which led to highly inconsistent results. Finally, (III.) combining PSS with exercises did

195 promote long-term postural recovery in a chronic population compared to a dose-and-

196 content-matched exercise group and these results persisted at follow-up.

197 One might concern that supplementary stimulation might increase risk of falling,

198 as the integration of additional input will increase cognitive demands. However, this

199 hypothesis cannot be confirmed by the current review. Firstly, immediately after PSS

200 performance on the Forward Reach Test ${ }^{27}$ and the BBS ${ }^{29}$ improved along with postural

201 sway normalization ${ }^{30}$. Secondly, adding PSS to exercises did not lead to more adverse

202 events or higher drop-out rates. Contrary, postural stability improved suggesting, if

203 anything, that additional stimulation can decrease fall risk after stroke.

PSS as a novel therapeutic strategy for postural recovery

205 In the introduction, PSS is suggested as a novel therapeutic strategy in postural

206 rehabilitation as it might restore somatosensation and increase postural contribution of

207 the paretic leg. Only a single trial measured weight-bearing symmetry and found

208 improvements after six weeks of stimulation and exercises ${ }^{25}$. One might suggest that

209 participants relied more on the paretic leg while keeping an upright posture. However, it

210 remains unclear whether symmetry remediated because of "true" recovery or a learned

211 compensation strategy, where true recovery is defined as restoring of a symmetric 
212 bearing of weight resulting from equal contribution of both legs to upright postural

213 stability ${ }^{20}$. In fact, only $10-20 \%$ of regulatory activity happened through the paretic leg

214 during upright standing ${ }^{43}$ and stroke survivors recovered without any improvements in

215 paretic leg regulatory activity ${ }^{44}$. Apparently, postural recovery after stroke is mainly

216 driven by compensatory strategies, e.g. shifting postural contribution to the non-paretic

217 side leading to weight-bearing asymmetry ${ }^{12,13}$. In the study of Goliwas et al. ${ }^{25}$, weight-

218 bearing symmetry gains did not reach significance during visual deprivation, a

219 condition where participants highly depend on somatosensory input from and regulatory

220 activity of the paretic leg in order to achieve symmetry. Therefore, improvements

221 during the eyes-open, but not during the eyes-closed condition, most likely suggest a

222 learned strategy based on visual information rather than an increase in paretic leg

223 postural contribution.

224 Still, some evidence supports the hypothesis. Somatosensory functions improved

27-29 and normalization of postural sway was more evident in the eyes closed condition

after PSS ${ }^{30,33,35}$. It is suggested that stimulation did promote central integration of

227 afferent input rising from the paretic leg, leading to a decrease in visual dependence

228 while maintaining an upright posture. However, these observations result from single

229 force plate set-ups which do not give definite insights to which extend the paretic leg is

230 involved in postural stability. A lack of evidence concerning PSS as a therapeutic

231 strategy to enhance paretic leg postural contribution is identified and future research is

232 warranted.

\section{Spinal and supra-spinal effects of PSS}

234 Immediate effects after PSS on postural stability ${ }^{24,26,27,29,30}$ are similar to those seen

235 after PSS to the upper limb, as performance on the Jebsen-Taylor Hand Function Test

236 improved immediately after combining PSS with training ${ }^{45,46}$. This indicates a close 
237 functional relation between somatosensory input and motor output. Underlying

238 mechanisms are an issue of discussion.

239 Some authors found reduced spasticity immediately post-stimulation ${ }^{30}$ and after

240 repetitive sessions of PSS ${ }^{31,34-36}$ in the current review. In animal studies, application of

241 TENS increased release of GABA in the dorsal horn ${ }^{47}$, which acts as an inhibitory

242 neurotransmitter to spinal reflex activity leading to a decrease in spasticity. This

243 mechanism is similar to baclofen and short-term effectiveness of both interventions is

244 found to be equivalent in a recent review ${ }^{48}$. The authors conclude that TENS is a safe

245 and effective adjuvant therapy in limb spasticity management.

246 Beside a possible spinal anti-spastic effect, evidence on supra-spinal effects is

247 growing. Stimulation to the hand led to increased blood flow in the primary

248 sensorimotor cortex ${ }^{49}$ and increased cortico-motor excitability ${ }^{17,49}$. How these cortical

249 sensorimotor interactions work is still unclear. Findings of Tyson et al. ${ }^{27}$ who observed

250 improved somatosensation along with improved postural stability during TENS might

251 suggest that enhanced afferent input is centrally transmitted to the primary sensory

252 cortex (S1) and that S1-activity drives motor cortex excitation leading to improved

253 motor output. Brodie et al. ${ }^{50}$ observed after non-invasive central stimulation to S1

254 improvements in somatosensory functions and motor learning. This reinforces the

255 increasingly clear importance of somatosensation in motor learning ${ }^{51}$ considering that

256 skill learning is an adaptive process triggered by afferent input as described by the

257 internal model ${ }^{52}$. Central sensory disorders, which are common after stroke ${ }^{8}$, may

258 disrupt this mechanism and hamper learning ${ }^{51}$ leading to poorer recovery ${ }^{42}$. PSS might

259 remediate somatosensory integration and restore learning capacity. Indeed, PSS

260 combined with exercises increased long-term postural recovery after stroke $31,32,35,36,40$. 
However, improved somatosensation after S1-stimulation showed only a small

262 effect on motor functions ${ }^{50}$ and Kaelin-Lang et al. ${ }^{17}$ found increased motor cortex excitability after PSS without any change in S1 excitability. The authors consider short-

264 term plastic changes in the motor cortex to be directly induced by afferent input, as the

265 motor cortex receives somatotopically projections from the sensory cortex ${ }^{17}$.

266 Apparently, somatosensory input can drive not only somatosensory but also motor

267 cortex excitability. Plastic changes in the motor cortex directly after PSS are probably

268 responsible for immediate functional improvements ${ }^{24,26,27,29,30}$. The immediate character

269 of these effects seems to mimic those seen after rapid motor learning ${ }^{53}$ suggesting that

270 afferent-induced changes in motor excitability is fundamental for learning.

271 The latter notion emphasizes PSS to be a potential adjuvant therapy in

272 rehabilitation after stroke. Considering that immediate ${ }^{24,26,27,29,30}$ and long-term

273 improvements ${ }^{6,25,31-33,35,36}$ are found in a chronic population, one might suggest that

274 enhanced afferent input triggers remaining plastic capacity for sensorimotor re-

275 organization. Therefore, the current review suggests PSS to be considered a motor

276 learning booster and a valuable adjuvant to task-oriented exercises in rehabilitation after

277 stroke.

278

279 Limitations of the current review

280 All included studies except for two RCTs ${ }^{23,32}$ present methodological weakness.

281 Observational trials lack a randomized-controlled design ${ }^{24,26,28,29}$ and the majority of

282 RCTs present low PEDro scores due to inadequate blinding of patients, therapists and/or

283 assessors and a lack of an intention-to-treat analysis $27,30,31,33,34,36-40$. In addition, PSS

284 approaches and dosage varied widely between studies. This prevents drawing firm

285 conclusions and therefore the readers should interpret the current review not as definite 
therapeutic guidelines, but rather a state-of-the-evidence document rising questions and giving recommendations for clinical practice and research.

289 Future trials of robust methodological quality and adequate blinding should take

290 characteristics of PSS into account: Postural stability improved immediately $24,26,27,29,30$

291 and stimulation prior to exercises is effective in improving recovery ${ }^{31,32,35}$. An

292 observational trial found a peak of cortical excitability at 45-60 minutes of PSS ${ }^{54}$,

293 similar to the amount of adjuvant PSS given in a high-quality clinical trial ${ }^{32}$.

294 Aftereffects are described by Walker et al. ${ }^{24}$. Similar, Golaszweksi et al. ${ }^{55}$ reported

295 effects $1 \mathrm{~h}$ after stimulation to be even stronger compared to immediate effects post-

296 stimulation. Kaelin-Lang et al. ${ }^{17}$ applied sensory stimulation to the nervus ulnaris and

297 found that motor evoked potentials of ulnar nerve-innervated muscles improved only.

298 To sum up, cortical effects of PSS are immediate, relatively short-lasting and focal. This

299 emphasizes, similar to the conclusion of the current review, that PSS is effective only as

300 an adjuvant therapy in improving functional recovery after stroke. If PSS should be

301 delivered above or below sensory threshold remains unclear. The current review found

302 beneficial effects after supra-sensory PSS $24,27,30-32,35,40$. However, Conforto et al. ${ }^{18}$

303 found sub-sensory PSS to facilitate motor training, similar to Park et al. ${ }^{36}$. This issue

304 needs further investigation.

305 Beside PSS characteristics, outcome measures should include dual force plate

306 posturography ${ }^{13}$ to gain insights to which extent the paretic leg contributes to postural

307 stability after PSS. Comparing different sensory conditions will further distinguish

308 between true or compensatory recovery. Finally, combining neuro-imaging with clinical

309 assessments can close the gap between fundamental and clinical research, which can

310 provide a groundwork to develop evidence-based rehabilitation strategies. 


\section{Conclusion}

313 Somatosensory integration is fundamental for postural stability and motor learning,

314 suggesting that enhancing somatosensory input during rehabilitation can promote

315 postural recovery gains after stroke. Indeed, PSS, in most included studies provided as

316 low-intensive electrical stimulation, is found to be effective immediately and on a long-

317 term as an adjuvant therapy only in improving postural stability in a chronic population.

318 However, a lack of evidence concerning PSS as therapeutic strategy to enhance paretic

319 leg postural contribution is identified. Future research is warranted considering those

320 promising results after exercise therapy combined with PSS and high prevalence of

321 postural instability impacting daily life of stroke survivors.

\section{Declarations of interest}

323 Finally, the author(s) declare no potential conflicts of interest with respect to the

324 authorship and/or publication of this article. 


\section{References}

326 1. Jorgensen HS, Nakayama H, Raaschou HO, Olsen TS. Recovery of walking

2. Wade DT, Wood VA, Heller A, Maggs J, Langton Hewer R. Walking after function in stroke patients: the Copenhagen Stroke Study. Arch Phys Med Rehabil. 1995;76(1):27-32.

stroke. Measurement and recovery over the first 3 months. Scand J Rehabil Med. 1987;19(1):25-30.

3. Paolucci S, Bragoni M, Coiro P, et al. Quantification of the probability of reaching mobility independence at discharge from a rehabilitation hospital in nonwalking early ischemic stroke patients: a multivariate study. Cerebrovasc Dis. 2008;26(1):16-22.

4. Kollen B, van de Port I, Lindeman E, Twisk J, Kwakkel G. Predicting improvement in gait after stroke: a longitudinal prospective study. Stroke. 2005;36(12):2676-2680.

5. Tyson SF, Hanley M, Chillala J, Selley A, Tallis RC. Balance disability after stroke. Phys Ther. 2006;86(1):30-38.

6. Ada L, Dorsch S, Canning CG. Strengthening interventions increase strength and improve activity after stroke: a systematic review. Aust $J$ Physiother. 2006;52(4):241-248.

7. Marigold DS, Eng JJ, Tokuno CD, Donnelly CA. Contribution of muscle strength and integration of afferent input to postural instability in persons with stroke. Neurorehabil Neural Repair. 2004;18(4):222-229.

8. Kessner SS, Bingel U, Thomalla G. Somatosensory deficits after stroke: a scoping review. Top Stroke Rehabil. 2016;23(2):136-146.

9. Niam S, Cheung W, Sullivan PE, Kent S, Gu X. Balance and physical impairments after stroke. Arch Phys Med Rehabil. 1999;80(10):1227-1233.

10. Hsu AL, Tang PF, Jan MH. Analysis of impairments influencing gait velocity and asymmetry of hemiplegic patients after mild to moderate stroke. Arch Phys Med Rehabil. 2003;84(8):1185-1193.

11. Geurts AC, de Haart M, van Nes IJ, Duysens J. A review of standing balance recovery from stroke. Gait Posture. 2005;22(3):267-281.

12. Kamphuis JF, de Kam D, Geurts AC, Weerdesteyn V. Is weight-bearing asymmetry associated with postural instability after stroke? A systematic review. Stroke Res Treat. 2013;2013:692137.

13. Roerdink M, Geurts AC, de Haart M, Beek PJ. On the relative contribution of the paretic leg to the control of posture after stroke. Neurorehabil Neural Repair. 2009;23(3):267-274.

14. Hendrickson J, Patterson KK, Inness EL, Mcllroy WE, Mansfield A. Relationship between asymmetry of quiet standing balance control and walking post-stroke. Gait Posture. 2014;39(1):177-181.

15. Nardone A, Godi M, Grasso M, Guglielmetti S, Schieppati M. Stabilometry is a predictor of gait performance in chronic hemiparetic stroke patients. Gait Posture. 2009;30(1):5-10.

16. Bonan IV, Colle FM, Guichard JP, et al. Reliance on visual information after stroke. Part I: Balance on dynamic posturography. Arch Phys Med Rehabil. 2004;85(2):268-273.

17. Kaelin-Lang A, Luft AR, Sawaki L, Burstein AH, Sohn YH, Cohen LG. Modulation of human corticomotor excitability by somatosensory input. $J$ Physiol. 2002;540(Pt 2):623-633.

18. Conforto $A B$, Ferreiro KN, Tomasi $C$, et al. Effects of somatosensory stimulation on motor function after subacute stroke. Neurorehabil Neural Repair. 2010;24(3):263-272.

19. Fleming MK, Sorinola IO, Roberts-Lewis SF, Wolfe CD, Wellwood I, Newham DJ. The effect of combined somatosensory stimulation and task-specific training 
on upper limb function in chronic stroke: a double-blind randomized controlled trial. Neurorehabil Neural Repair. 2015;29(2):143-152.

20. Anker LC, Weerdesteyn V, van Nes IJ, Nienhuis B, Straatman H, Geurts AC. The relation between postural stability and weight distribution in healthy subjects. Gait Posture. 2008;27(3):471-477.

21. Liberati A, Altman DG, Tetzlaff $\mathrm{J}$, et al. The PRISMA statement for reporting systematic reviews and meta-analyses of studies that evaluate healthcare interventions: explanation and elaboration. BMJ. 2009;339:b2700.

22. Harbour R, Miller J. A new system for grading recommendations in evidence based guidelines. BMJ. 2001;323(7308):334-336.

23. Paoloni M, Mangone M, Scettri P, Procaccianti R, Cometa A, Santilli V. Segmental muscle vibration improves walking in chronic stroke patients with foot drop: a randomized controlled trial. Neurorehabil Neural Repair. 2010;24(3):254-262.

24. Walker ER, Hyngstrom AS, Schmit BD. Sensory electrical stimulation improves foot placement during targeted stepping post-stroke. Exp Brain Res. 2014;232(4):1137-1143.

25. Goliwas M, Kocur P, Furmaniuk L, Majchrzycki M, Wiernicka M, Lewandowski J. Effects of sensorimotor foot training on the symmetry of weight distribution on the lower extremities of patients in the chronic phase after stroke. J Phys Ther Sci. 2015;27(9):2925-2930.

26. Kawahira K, Higashihara K, Matsumoto S, et al. New functional vibratory stimulation device for extremities in patients with stroke. Int J Rehabil Res. 2004;27(4):335-337.

27. Tyson SF, Sadeghi-Demneh E, Nester CJ. The effects of transcutaneous electrical nerve stimulation on strength, proprioception, balance and mobility in people with stroke: a randomized controlled cross-over trial. Clin Rehabil. 2013;27(9):785-791.

28. Peurala SH, Pitkanen K, Sivenius J, Tarkka IM. Cutaneous electrical stimulation may enhance sensorimotor recovery in chronic stroke. Clin Rehabil. 2002;16(7):709-716.

29. Kim YD, Lee KB, Roh HL. Immediate effects of the activation of the affected lower limb on the balance and trunk mobility of hemiplegic stroke patients. $J$ Phys Ther Sci. 2015;27(5):1555-1557.

30. Cho HY, In TS, Cho KH, Song $\mathrm{CH}$. A single trial of transcutaneous electrical nerve stimulation (TENS) improves spasticity and balance in patients with chronic stroke. Tohoku J Exp Med. 2013;229(3):187-193.

31. $\mathrm{Ng} \mathrm{SS}$, Hui-Chan CW. Transcutaneous electrical nerve stimulation combined with task-related training improves lower limb functions in subjects with chronic stroke. Stroke. 2007;38(11):2953-2959.

32. $\mathrm{Ng} \mathrm{SS}$, Hui-Chan CW. Does the use of TENS increase the effectiveness of exercise for improving walking after stroke? A randomized controlled clinical trial. Clin Rehabil. 2009;23(12):1093-1103.

33. Lee SW, Cho KH, Lee WH. Effect of a local vibration stimulus training programme on postural sway and gait in chronic stroke patients: a randomized controlled trial. Clin Rehabil. 2013;27(10):921-931.

34. Laddha D, Ganesh GS, Pattnaik M, Mohanty P, Mishra C. Effect of Transcutaneous Electrical Nerve Stimulation on Plantar Flexor Muscle Spasticity and Walking Speed in Stroke Patients. Physiother Res Int. 2016;21(4):247-256.

35. Jung KS, In TS, Cho HY. Effects of sit-to-stand training combined with transcutaneous electrical stimulation on spasticity, muscle strength and balance ability in patients with stroke: A randomized controlled study. Gait Posture. 2017;54:183-187. 
461

462

463

464

465

466

467

468

469

470

471

472

473

474

475

476

477

478

479

480

481

482

483

484

485

486

36. Park J, Seo D, Choi W, Lee S. The effects of exercise with TENS on spasticity, balance, and gait in patients with chronic stroke: a randomized controlled trial. Med Sci Monit. 2014;20:1890-1896.

37. Yavuzer G, Oken O, Atay MB, Stam HJ. Effect of sensory-amplitude electric stimulation on motor recovery and gait kinematics after stroke: a randomized controlled study. Arch Phys Med Rehabil. 2007;88(6):710-714.

38. Chen JC, Lin CH, Wei YC, Hsiao J, Liang CC. Facilitation of motor and balance recovery by thermal intervention for the paretic lower limb of acute stroke: a single-blind randomized clinical trial. Clin Rehabil. 2011;25(9):823-832.

39. Liang CC, Hsieh TC, Lin CH, Wei YC, Hsiao J, Chen JC. Effectiveness of thermal stimulation for the moderately to severely paretic leg after stroke: serial changes at one-year follow-up. Arch Phys Med Rehabil. 2012;93(11):19031910.

40. Ng SS, Lai CW, Tang MW, Woo J. Cutaneous electrical stimulation to improve balance performance in patients with sub-acute stroke: a randomised controlled trial. Hong Kong Med J. 2016;22 Suppl 2:S33-36.

41. Hsu HW, Lee CL, Hsu MJ, et al. Effects of noxious versus innocuous thermal stimulation on lower extremity motor recovery 3 months after stroke. Arch Phys Med Rehabil. 2013;94(4):633-641.

42. Tyson SF, Hanley M, Chillala J, Selley AB, Tallis RC. Sensory loss in hospitaladmitted people with stroke: characteristics, associated factors, and relationship with function. Neurorehabil Neural Repair. 2008;22(2):166-172.

43. van Asseldonk EH, Buurke $\mathrm{JH}$, Bloem BR, et al. Disentangling the contribution of the paretic and non-paretic ankle to balance control in stroke patients. Exp Neurol. 2006;201(2):441-451.

44. de Haart M, Geurts AC, Huidekoper SC, Fasotti L, van Limbeek J. Recovery of standing balance in postacute stroke patients: a rehabilitation cohort study. Arch Phys Med Rehabil. 2004;85(6):886-895.

45. Celnik P, Hummel F, Harris-Love M, Wolk R, Cohen LG. Somatosensory stimulation enhances the effects of training functional hand tasks in patients with chronic stroke. Arch Phys Med Rehabil. 2007;88(11):1369-1376.

46. Wu CW, Seo HJ, Cohen LG. Influence of electric somatosensory stimulation on paretic-hand function in chronic stroke. Arch Phys Med Rehabil. 2006;87(3):351-357.

47. Maeda Y, Lisi TL, Vance CG, Sluka KA. Release of GABA and activation of GABA(A) in the spinal cord mediates the effects of TENS in rats. Brain Res. 2007;1136(1):43-50.

48. Mills PB, Dossa F. Transcutaneous Electrical Nerve Stimulation for Management of Limb Spasticity: A Systematic Review. Am J Phys Med Rehabil. 2016;95(4):309-318.

49. Golaszewski SM, Siedentopf CM, Koppelstaetter F, et al. Modulatory effects on human sensorimotor cortex by whole-hand afferent electrical stimulation. Neurology. 2004;62(12):2262-2269.

50. Brodie SM, Meehan S, Borich MR, Boyd LA. $5 \mathrm{~Hz}$ repetitive transcranial magnetic stimulation over the ipsilesional sensory cortex enhances motor learning after stroke. Front Hum Neurosci. 2014;8:143.

51. Borich MR, Brodie SM, Gray WA, lonta S, Boyd LA. Understanding the role of the primary somatosensory cortex: Opportunities for rehabilitation. Neuropsychologia. 2015;79(Pt B):246-255.

52. Ito M. Mechanisms of motor learning in the cerebellum. Brain Res. 2000;886(12):237-245.

53. Muellbacher W, Ziemann U, Boroojerdi B, Cohen L, Hallett M. Role of the human motor cortex in rapid motor learning. Exp Brain Res. 2001;136(4):431438. 
54. McKay D, Brooker R, Giacomin P, Ridding M, Miles T. Time course of induction of increased human motor cortex excitability by nerve stimulation. Neuroreport. 2002;13(10):1271-1273.

55. Golaszewski SM, Bergmann J, Christova M, et al. Modulation of motor cortex excitability by different levels of whole-hand afferent electrical stimulation. Clin Neurophysiol. 2012;123(1):193-199. 
Table 1: assessing methodological quality adapted from the SIGN guidelines

\begin{tabular}{|c|l|}
\hline $1++$ & RCT's with a very low risk of bias (high quality) \\
\hline $1+$ & RCT's with a low risk of bias (fair quality) \\
\hline $1-$ & RCT's with a high risk of bias (poor quality) \\
\hline $2+$ & well conducted observational studies with a low risk of bias (fair quality) \\
\hline $2-$ & observational studies with a high risk of bias (poor quality) \\
\hline
\end{tabular}

Table 2: rating level of evidence adapted from the SIGN guidelines

\begin{tabular}{|l|l|}
\hline & Conclusion based on ... \\
\hline A & $\geq 1$ study of $1++$ quality or $\geq 2$ studies of $1+$ quality \\
\hline B & $\geq 2$ studies with a quality of at least $2++$ \\
\hline C & $\geq 2$ studies with a quality of $2+$ \\
\hline D & lower \\
\hline
\end{tabular}


Table 3: characteristics of included studies, observed effects $(*, p<0.05 ; \uparrow, p<0.01)$ and methodological quality

\begin{tabular}{|c|c|c|c|c|c|c|}
\hline & population & intervention & control & $\begin{array}{l}\text { time effect (difference } \\
\text { pre/post within group) }\end{array}$ & $\begin{array}{l}\text { interaction effect (difference } \\
\text { pre/post between groups) }\end{array}$ & MQ \\
\hline \multicolumn{7}{|c|}{ (I.) immediate effects of a single session PSS } \\
\hline $\begin{array}{l}\text { Kawahira } \\
2004^{26}\end{array}$ & $\begin{array}{l}\text { chronic }(>5 \mathrm{~m}) \text {; walk } \\
10 \mathrm{~m} \text { with aid; } \mathrm{N}=13\end{array}$ & $\begin{array}{l}\text { during loc vib }(83 \mathrm{~Hz}) \text { to } \mathrm{m} \text {. tib } \\
\text { ant and } \mathrm{m} \text {. glut med }\end{array}$ & I & gait speed $(+0.05 \mathrm{~m} / \mathrm{s}) \dagger$ & & $2-$ \\
\hline $\begin{array}{l}\text { Walker } \\
2014^{24}\end{array}$ & $\begin{array}{l}\text { chronic }(>6 \mathrm{~m}) \text {; walk } \\
\text { independently; } \mathrm{N}=12\end{array}$ & $\begin{array}{l}\text { during SES }(95 \% \text { motor } \\
\text { threshold, } 30 \mathrm{~Hz}) \text { to malleolis } \\
\text { med }\end{array}$ & l & $\begin{array}{l}\text { foot placement ML† AP, } \\
\text { gait kinematics (less hip } \\
\text { circumduction } \dagger \text { ) }\end{array}$ & & $2+$ \\
\hline $\begin{array}{l}\text { Tyson } \\
2013^{27}\end{array}$ & $\begin{array}{l}\text { chronic; standing } \\
\text { independently } 20 \mathrm{~s} \\
\mathrm{~N}=29\end{array}$ & $\begin{array}{l}\text { during TENS via sock-electrode } \\
(>\text { sens threshold, } 70-130 \mathrm{~Hz})\end{array}$ & sham & & $\begin{array}{l}\text { forward reach }(+4.16 \mathrm{~cm}) \dagger \text {, } \\
\text { gait speed }(+0.03 \mathrm{~m} / \mathrm{s}) \dagger\end{array}$ & $1+$ \\
\hline $\begin{array}{l}\text { Kim } \\
2015^{29}\end{array}$ & $\begin{array}{l}\text { chronic; } \mathrm{N}=12 \text { ( } 6 \\
\text { walker, } 6 \text { non-walker) }\end{array}$ & $\begin{array}{l}\text { immediately after } 30 \mathrm{~min} \text { hands- } \\
\text { on foot activation }\end{array}$ & l & $\operatorname{BBS}(+5,25)^{*}$ & & $2-$ \\
\hline $\begin{array}{l}\text { Cho } \\
2013^{30}\end{array}$ & $\begin{array}{l}\text { chronic }(14,5 \mathrm{~m}) \text {; } \\
\text { spasticity; stand } \\
\text { unassisted } 10 \mathrm{~min} ; \mathrm{N}=42\end{array}$ & $\begin{array}{l}\text { immediately after } 60 \text { min of } \\
\text { TENS ( } 2-3 x \text { sens threshold, } \\
100 \mathrm{~Hz} \text { ) to m. gastro }\end{array}$ & sham & $\begin{array}{l}\text { COPdis EO }(-10.14 \mathrm{~cm})^{*} \\
\text { EC }(-20.74 \mathrm{~cm})^{*}, \text { US EO }(- \\
34.76 \mathrm{~cm})^{*}\end{array}$ & $\begin{array}{l}\text { COPdis EO }(-10.14 \mathrm{~cm})^{*}, \text { EC } \\
(-20.74 \mathrm{~cm})^{*}, \text { US EO }(- \\
34.76 \mathrm{~cm})^{*}\end{array}$ & $1-$ \\
\hline \multicolumn{7}{|c|}{ (II.) repetitive sessions of isolated PSS } \\
\hline $\begin{array}{l}\text { Chen } \\
2011^{38}\end{array}$ & $\begin{array}{l}\text { acute }(<4 w) ; B S<4 \\
\text { FAC }<2 ; N=36\end{array}$ & $6 \mathrm{w}$ thermal stim for $48 \mathrm{~min}, 5 \mathrm{x} / \mathrm{w}$ & $\begin{array}{l}\text { talking } \\
\text { session }\end{array}$ & $\begin{array}{l}\text { BBS }(+28.0) \dagger, \text { mMAS } \\
(+16.0) \dagger, \text { FAC }(+2) \dagger\end{array}$ & $\begin{array}{l}\text { BBS }(+7.5) \dagger, \text { mMAS }(+6) \dagger, \\
\operatorname{FAC~}(+1) \dagger\end{array}$ & $1+$ \\
\hline
\end{tabular}




\begin{tabular}{|c|c|c|c|c|c|c|}
\hline $\begin{array}{l}\text { Liang } \\
2012^{39}\end{array}$ & $\begin{array}{l}\text { acute }(<4 w) ; B S<4 \\
N=30\end{array}$ & $6 \mathrm{w}$ thermal stim for $40 \mathrm{~min}, 5 \mathrm{x} / \mathrm{w}$ & $\begin{array}{l}\text { talking } \\
\text { session }\end{array}$ & $\begin{array}{l}\text { BBS }(+30,3) \dagger, \text { mMAS } \\
(+18,3) \dagger, \text { FAC }(+2,3) \dagger\end{array}$ & $\begin{array}{l}\text { BBS }(+9.3), \text { mMAS }(+6,5) \dagger \\
\text { FAC }(+0.8) \dagger\end{array}$ & $1+$ \\
\hline $\begin{array}{l}\text { Hsu } \\
2013^{41}\end{array}$ & $\begin{array}{l}\text { subacute }(>3 \mathrm{~m}) \text {; sit } \\
\text { independently }>30 \mathrm{~min} \text {; } \\
\mathrm{N}=23\end{array}$ & $\begin{array}{l}8 \mathrm{w} \text { noxious thermal stim for } \\
30 \mathrm{~min}, 3 \mathrm{x} / \mathrm{w}\end{array}$ & $\begin{array}{l}\text { innocu } \\
\text { ous } \\
\text { stim }\end{array}$ & $\begin{array}{l}\text { PASS }(+1.1), \text { mob- } \\
\text { STREAM }(+2.8) \dagger, \text { FAC } \\
(+0.8) \dagger\end{array}$ & $\begin{array}{l}\text { PASS }(+0.9), \text { mob-STREAM } \\
(+2.5), \text { FAC }(+0.4)\end{array}$ & $1+$ \\
\hline $\begin{array}{l}\text { Peurala } \\
2002^{28}\end{array}$ & chronic $(+-3,3 y) ; N=19$ & $\begin{array}{l}3 \mathrm{w} \text { SES via sock-electrode (sub- } \\
\text { sens, } 50 \mathrm{~Hz} \text { ) for } 2 \times 20 \mathrm{~min} \\
2 \mathrm{x} / \text { day }\end{array}$ & / & $\begin{array}{l}\text { gait speed }(+0.03 \mathrm{~m} / \mathrm{s}) \\
\text { mMAS }(+2.4)^{*}\end{array}$ & & $2+$ \\
\hline $\begin{array}{l}\text { Yavuzer } \\
2007^{37}\end{array}$ & $\begin{array}{l}\text { subacute }(+-3,5 \mathrm{mos}) \\
\mathrm{BS}<4 ; \text { stand } \\
\text { unassisted; } \mathrm{N}=30\end{array}$ & $\begin{array}{l}4 \mathrm{w} \text { SES to } \mathrm{n} . \text { peron }(>\text { sens } \\
\text { threshold, } 35 \mathrm{~Hz} \text { ) for } 30 \mathrm{~min} \text {, } \\
5 \mathrm{x} / \mathrm{w}\end{array}$ & no stim & $\begin{array}{l}\text { gait kinematics, ST gait } \\
\text { analysis, gait speed }(+0.03 \\
\mathrm{m} / \mathrm{s})\end{array}$ & $\begin{array}{l}\text { gait kinematics, ST gait } \\
\text { analysis, gait speed }(+0.02 \\
\mathrm{m} / \mathrm{s})\end{array}$ & $1+$ \\
\hline $\begin{array}{l}\mathrm{Ng} \\
2007^{31}\end{array}$ & $\begin{array}{l}\text { chronic }(>1 \mathrm{y}) ; \text { walk } \\
10 \mathrm{~m} \text { unassisted; } \\
\text { spasticity; } \mathrm{N}=88\end{array}$ & $\begin{array}{l}4 \mathrm{w} \text { TENS }(2-3 \mathrm{x} \text { sens threshold, } \\
100 \mathrm{~Hz}) \text { to } \mathrm{n} \text {. peronealis for } 60 \\
\mathrm{~min}, 5 \mathrm{x} / \mathrm{w}\end{array}$ & no stim & gait speed $(+0.08 \mathrm{~m} / \mathrm{s})$ & gait speed $(+0.07 \mathrm{~m} / \mathrm{s})$ & $1+$ \\
\hline $\begin{array}{l}\mathrm{Ng} \\
2009^{32}\end{array}$ & $\begin{array}{l}\text { chronic }(>1 y) \\
\text { spasticity; } N=109\end{array}$ & $\begin{array}{l}4 \mathrm{w} \text { TENS }(2 \mathrm{x} \text { sens threshold, } \\
100 \mathrm{~Hz} \text { ) to n. peronealis for } 60 \\
\mathrm{~min}, 5 \mathrm{x} / \mathrm{w}\end{array}$ & no stim & $\begin{array}{l}\text { gait speed }(+0.03 \mathrm{~m} / \mathrm{s}), \\
6 \mathrm{MWT}(+18.4 \mathrm{~cm}), \text { TUG }(- \\
2.1)\end{array}$ & $\begin{array}{l}\text { gait speed }(+0.01 \mathrm{~m} / \mathrm{s}), 6 \mathrm{MWT} \\
(+17.8 \mathrm{~cm}), \text { TUG }(-2.1) \dagger\end{array}$ & $1++$ \\
\hline \multicolumn{7}{|c|}{ (III.) repetitive sessions of PSS combined with exercises } \\
\hline $\begin{array}{l}\text { Lee } \\
2013^{33}\end{array}$ & $\begin{array}{l}\text { chronic (>6 months); } \\
\text { walk } 10 \mathrm{~m} \\
\text { independently; } \mathrm{N}=34\end{array}$ & $\begin{array}{l}\text { 6w EX during loc vib }(90 \mathrm{~Hz}) \text { to } \\
\text { achilles tendon and } \mathrm{m} \text {. tib ant for } \\
30 \mathrm{~min}, 3 \mathrm{x} / \mathrm{w}\end{array}$ & $\begin{array}{l}\mathrm{EX}+ \\
\text { sham }\end{array}$ & $\begin{array}{l}\text { COPdis EO }(-11.91)^{*}, \text { EC } \\
(-20.67)^{*}, \text { COPv EO }(- \\
0.40)^{*}, \text { EC }(-0.69)^{*}, \text { ST gait } \\
\text { analysis*, gait speed }(+0.15 \\
\text { m/s)* }\end{array}$ & $\begin{array}{l}\text { COPdis EO }(-12.71)^{*}, \text { EC }(- \\
20.33)^{*}, \text { COPv EO }(-0.43)^{*} \\
\text { EC }(-0.68)^{*}, \text { ST gait } \\
\text { analysis*, gait speed }(+0.12 \\
\text { m/s)* }\end{array}$ & $1+$ \\
\hline
\end{tabular}




\begin{tabular}{|c|c|c|c|c|c|c|}
\hline $\begin{array}{l}\text { Laddha } \\
2016^{34}\end{array}$ & $\begin{array}{l}\text { chronic (+-15,7 m); } \\
\text { spasticity; walk } 10 \mathrm{~m} \\
\text { unassisted; } N=30\end{array}$ & $\begin{array}{l}6 \mathrm{w} \text { EX }+ \text { prior } 30 \text { or } 60 \mathrm{~min} \\
\text { TENS }(2-3 \mathrm{x} \text { sens threshold, } \\
100 \mathrm{~Hz}) \text { to } \mathrm{n} \text {. peron, } 5 \mathrm{x} / \mathrm{w}\end{array}$ & EX & TUG $(\mathrm{n} / \mathrm{r}) *$ & TUG (n/r) & $1-$ \\
\hline $\begin{array}{l}\text { Jung } \\
2017^{35}\end{array}$ & $\begin{array}{l}\text { chronic }(6,5 \mathrm{~m}) ; \text { sit-to- } \\
\text { stand unassisted; } \\
\text { spasticity; } \mathrm{BS}=3 ; \mathrm{N}=40\end{array}$ & $\begin{array}{l}\text { 6w EX + prior } 30 \mathrm{~min} \text { TENS }(2 \mathrm{x} \\
\text { sens threshold, } 100 \mathrm{~Hz}) \text { to } \mathrm{n} . \\
\text { peron, } 5 \mathrm{x} / \mathrm{w}\end{array}$ & $\begin{array}{l}\text { EX + } \\
\text { sham }\end{array}$ & $\begin{array}{l}\text { COPdis EO }(-21.0 \mathrm{~cm})^{*} \\
\text { COPdis EC }(-26.4 \mathrm{~cm})^{*}\end{array}$ & $\begin{array}{l}\text { COPdis EO }(-12.2 \mathrm{~cm})^{*} \\
\text { COPdis EC }(-13.3 \mathrm{~cm})^{*}\end{array}$ & $1+$ \\
\hline $\begin{array}{l}\mathrm{Ng} \\
2007^{31}\end{array}$ & $\begin{array}{l}\text { chronic }(>1 \mathrm{y}) ; \text { walk } \\
\text { 10m unassisted; } \\
\text { spasticity; } \mathrm{N}=88\end{array}$ & $\begin{array}{l}4 \mathrm{w} \text { EX }+60 \text { min prior TENS }(2- \\
3 \mathrm{x} \text { sens threshold, } 100 \mathrm{~Hz}) \text { to } \mathrm{n} . \\
\text { peron, } 5 \mathrm{x} / \mathrm{w}\end{array}$ & $\begin{array}{l}\text { EX + } \\
\text { sham }\end{array}$ & gait speed $(+0.13 \mathrm{~m} / \mathrm{s}) \dagger$ & gait speed $(+0.09 \mathrm{~m} / \mathrm{s}) \dagger$ & $1+$ \\
\hline $\begin{array}{l}\mathrm{Ng} \\
2009^{32}\end{array}$ & $\begin{array}{l}\text { chronic (>1y); } \\
\text { spasticity; } N=109\end{array}$ & $\begin{array}{l}4 \mathrm{w} \text { EX }+60 \text { min prior TENS }(2 \mathrm{x} \\
\text { sens threshold, } 100 \mathrm{~Hz}) \text { to } \mathrm{n} . \\
\text { peron, } 5 \mathrm{x} / \mathrm{w}\end{array}$ & $\begin{array}{l}\text { EX + } \\
\text { sham }\end{array}$ & $\begin{array}{l}\text { gait speed }(+0.19 \mathrm{~m} / \mathrm{s}) \dagger \\
\text { 6MWT }(+50.1 \mathrm{~cm}), \text { TUG }(- \\
6.8)\end{array}$ & $\begin{array}{l}\text { gait speed }(+0.09 \mathrm{~m} / \mathrm{s}) \dagger \\
6 \mathrm{MWT}(+19.3 \mathrm{~cm}) \dagger, \text { TUG }(- \\
3.6) \dagger\end{array}$ & $1++$ \\
\hline $\begin{array}{l}\mathrm{Ng} \\
2016^{40}\end{array}$ & $\begin{array}{l}\text { acute }(6,2 \mathrm{w}) ; \text { stand } \\
1 \mathrm{~min} \text { unassisted; FAC } \\
>2 ; \mathrm{N}=76\end{array}$ & $\begin{array}{l}8 \mathrm{w} \text { EX }+ \text { prior } 60 \mathrm{~min} \text { TENS }(2 \mathrm{x} \\
\text { sens threshold, } 100 \mathrm{~Hz}) \text { to } \mathrm{n} . \\
\text { peron, } 2 \mathrm{x} / \mathrm{w}\end{array}$ & $\begin{array}{l}\text { EX + } \\
\text { sham }\end{array}$ & $\begin{array}{l}\text { BBS }(+9.9) \dagger, 6 \mathrm{MWT} \\
(+69.9 \mathrm{~m}) \dagger, \mathrm{TUG}(+20.1 \mathrm{~s}) \dagger\end{array}$ & $\begin{array}{l}\text { BBS }(+1.1) \dagger, 6 \mathrm{MWT}(+5.9 \mathrm{~m}) \\
\text { TUG }(+6.2 \mathrm{~s}) \dagger\end{array}$ & $1+$ \\
\hline \multicolumn{7}{|c|}{$\begin{array}{l}\text { MQ, methodological quality; PSS, peripheral somatosensory stimulation; m, months; w, weeks; min, minutes; loc vib, local vibration; SES, sensory- } \\
\text { amplitude electrical stimulation; ML, medio-lateral; AP, antero-posterior; BBS, Berg Balance Scale; COPdis, displacement of center-of-pressure; } \\
\text { COPv velocity of displacement of center-of-pressure; EO, eyes open; EC, eyes closed; US, unsupported surface; UC, usual care; FAC, Functional } \\
\text { Ambulation Classification; BS, Brunnstrom Stages of Stroke Recovery; mMAS, modified Motor Assessment Scale; PASS, Postural Assessment } \\
\text { Scale for Stroke Survivors; mob-STREAM, mobility section of the Stroke Rehabiliation Assessment of Movement; ST, spatiotemporal; 6MWT, 6- } \\
\text { Minute Walking Test; TUG, Timed-up and Go Test; EX, exercises }\end{array}$} \\
\hline
\end{tabular}


504 Search Strategy in PubMed:

505 ("Cerebrovascular Disorders/rehabilitation"[Mesh] OR "Stroke/rehabilitation"[Mesh] OR "Stroke Rehabilitation"[Mesh] OR

506 "Stroke/therapy"[Mesh]) AND ("Sensation/rehabilitation"[Mesh] OR "Somatosensory disorders/rehabilitation"[Mesh] OR "Somatosensory

507 Disorders/therapy"[Mesh] OR "Hypesthesia/rehabilitation"[Mesh] OR "proprioception"[Mesh] OR "physical stimulation"[Mesh] OR

508 "Transcutaneous Electric Nerve Stimulation"[Mesh] OR "pressure"[Mesh] OR "touch"[Mesh] OR "Vibration/therapeutic use"[Mesh] OR

509 "Electric Stimulation Therapy"[Mesh] OR stimulation[All Fields] OR "somatosensory stimulation"[All Fields]) AND ("gait"[Mesh] OR

510 "postural balance"[Mesh] OR "walking"[Mesh] OR "activities of daily living”[Mesh]) 
table 1: assessing methodological quality adapted from the SIGN guidelines

\begin{tabular}{|l|l|}
\hline $1++$ & RCT's with a very low risk of bias \\
\hline $1+$ & RCT's with a low risk of bias \\
\hline $1-$ & RCT's with a high risk of bias \\
\hline $2++$ & high-quality observational studies with a very low risk of bias \\
\hline $2+$ & well conducted observational studies with a low risk of bias \\
\hline $2-$ & observational studies with a high risk of bias \\
\hline
\end{tabular}

table 2: rating level of evidence adapted from the SIGN guidelines

\begin{tabular}{|l|l|}
\hline & Conclusion based on \\
\hline A & $\geq 1$ study of $1++$ quality or $\geq 2$ studies of $1+$ quality \\
\hline B & $\geq 2$ studies with a quality of at least $2++$ \\
\hline C & $\geq 2$ studies with a quality of $2+$ \\
\hline D & Lower \\
\hline
\end{tabular}


figure 1: detailed flowchart of search process with reasons of exclusion

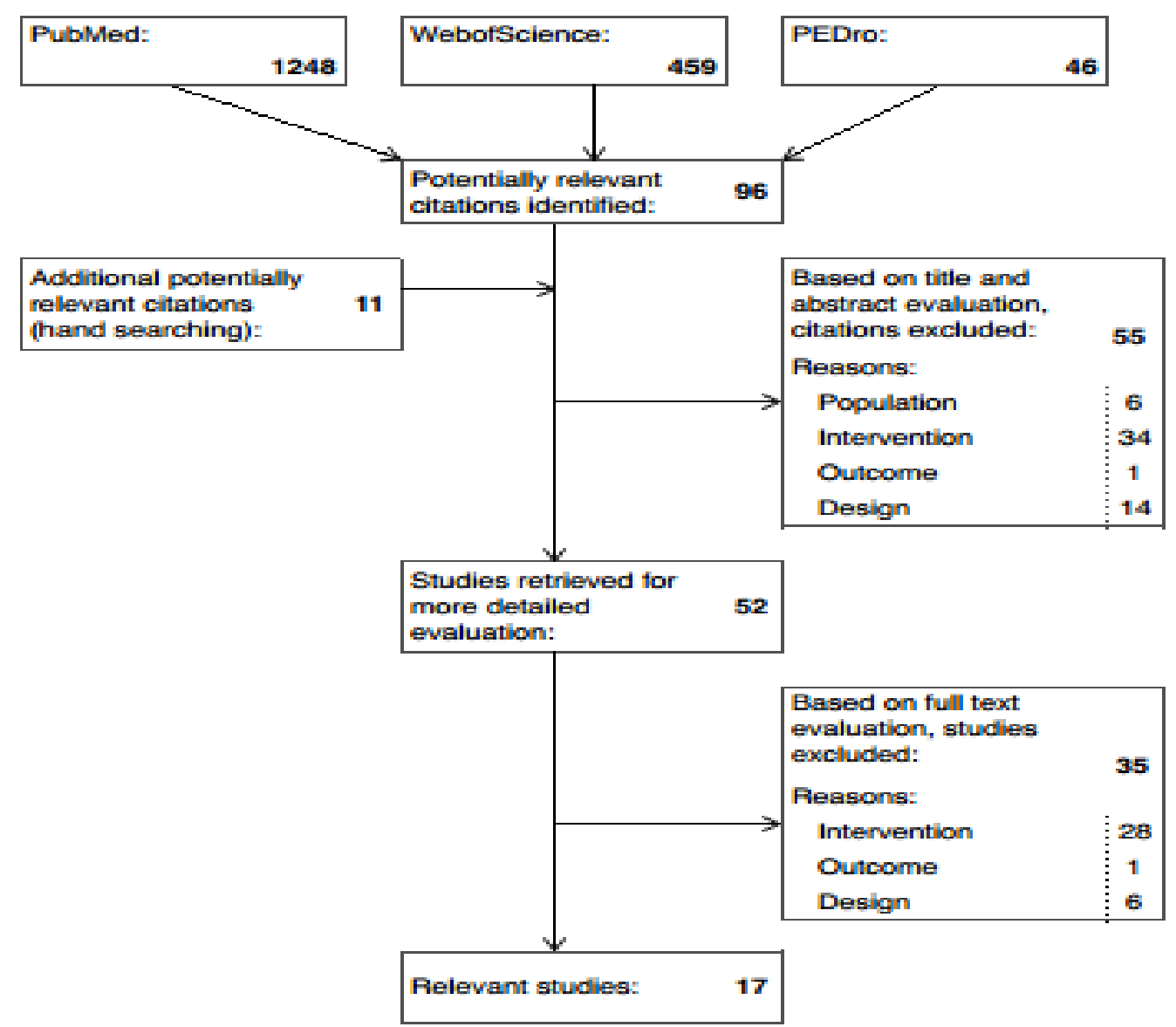


table 3: characteristics and methodological quality of included studies

\begin{tabular}{|c|c|c|c|c|c|}
\hline artikel & population & intervention & control/compare & $\begin{array}{l}\text { PEDro/ } \\
\text { NOS* }\end{array}$ & quality \\
\hline $\begin{array}{l}\text { Chan, } \\
2012\end{array}$ & $\begin{array}{l}\text { chronic }(>6 \mathrm{~m}), \text { walking } \\
100 \mathrm{~m} ; \mathrm{N}=32\end{array}$ & $\begin{array}{l}\text { single session WBV }(12 \mathrm{~Hz}) \\
2 \times 10 \mathrm{~min}\end{array}$ & sham & $8 / 10$ & $1+$ \\
\hline $\begin{array}{l}\text { van Nes, } \\
2004\end{array}$ & $\begin{array}{l}\text { chronic }(>6 \mathrm{~m}) \text {; stand } 30 \mathrm{~s} ; \\
\mathrm{N}=23\end{array}$ & $\begin{array}{l}\text { single session WBV }(30 \mathrm{~Hz}, \\
3 \mathrm{~mm} \text { amplitude) } 4 \times 45 \mathrm{sec}\end{array}$ & & $4 / 6^{*}$ & $2+$ \\
\hline $\begin{array}{l}\text { van Nes, } \\
2006\end{array}$ & acute $(<6 \mathrm{w}) ; \mathrm{BBS}<40 ; \mathrm{N}=53$ & $\begin{array}{l}\mathrm{SC}+6 \text { weeks WBV }(30 \mathrm{~Hz}, \\
3 \mathrm{~mm} \text { amplitude }) 4 \times 45 \sec 5 \mathrm{x} / \mathrm{w}\end{array}$ & $\mathrm{SC}+$ exercises & $3 / 6^{*}$ & $2-$ \\
\hline $\begin{array}{l}\text { Paoloni, } \\
2010\end{array}$ & $\begin{array}{l}\text { chronic }(>6 \mathrm{~m}) \text {; walk } 10 \mathrm{~m} \\
\text { unassisted, foot drop; } \mathrm{N}=44\end{array}$ & $\begin{array}{l}\text { SC }+4 \text { weeks local vibration } \\
(120 \mathrm{~Hz}) 30 \mathrm{~min} 3 \mathrm{x} / \mathrm{w}\end{array}$ & $\mathrm{SC}$ & $8 / 10$ & $1+$ \\
\hline $\begin{array}{l}\text { Kawahira, } \\
2004\end{array}$ & $\begin{array}{l}\text { chronic }(>5 \mathrm{~m}) \text {; walk with aid; } \\
\mathrm{N}=13\end{array}$ & $\begin{array}{l}\text { single session local vibration } \\
(83 \mathrm{~Hz})\end{array}$ & & $8 / 10$ & $1+$ \\
\hline $\begin{array}{l}\text { Chen, } \\
2011\end{array}$ & $\begin{array}{l}\text { acute }(<4 w) ; \mathrm{BS}<4, \mathrm{FAC}<2 ; \\
\mathrm{N}=36\end{array}$ & $\begin{array}{l}\mathrm{SC}+6 \mathrm{w} \text { thermal intervention } \\
48 \mathrm{~min} 5 \mathrm{x} / \mathrm{w}\end{array}$ & $\begin{array}{l}\mathrm{SC}+\text { talking } \\
\text { sessions }\end{array}$ & $7 / 10$ & $1-$ \\
\hline $\begin{array}{l}\text { Liang, } \\
2012\end{array}$ & acute $(<4 w) ; B S<4 ; N=30$ & $\begin{array}{l}\mathrm{SC}+6 \mathrm{w} \text { thermal intervention } \\
40 \mathrm{~min} 5 \mathrm{x} / \mathrm{w}\end{array}$ & $\begin{array}{l}\mathrm{SC}+\text { talking } \\
\text { sessions }\end{array}$ & $7 / 10$ & $1-$ \\
\hline Hsu, 2013 & $\begin{array}{l}\text { subacute }(>3 \mathrm{~m}) ; \text { sit } \\
\text { independently }>30 \mathrm{~min} ; \mathrm{N}=23\end{array}$ & $\begin{array}{l}\mathrm{SC}+8 \mathrm{w} \text { noxious stimulation } \\
30 \mathrm{~min} 3 \mathrm{x} / \mathrm{w}\end{array}$ & $\begin{array}{l}\mathrm{SC}+\text { innocuous } \\
\text { stimulation }\end{array}$ & $6 / 10$ & $1-$ \\
\hline $\begin{array}{l}\text { Walker, } \\
2014\end{array}$ & $\begin{array}{l}\text { chronic }(>6 \mathrm{~m}) ; \text { walk } \\
\text { independently; } \mathrm{N}=12\end{array}$ & $\begin{array}{l}\text { single session CES to } \mathrm{n} \text {. } \\
\text { plantaris med. (supra-sens, bi- } \\
\text { phasic, } 30 \mathrm{~Hz} \text { ), while active }\end{array}$ & & $5 / 6^{*}$ & $2+$ \\
\hline $\begin{array}{l}\text { Tyson, } \\
2013\end{array}$ & $\begin{array}{l}\text { chronic; standing } \\
\text { independently 20s; } \mathrm{N}=29\end{array}$ & $\begin{array}{l}\text { single session CES via sock- } \\
\text { electrode (supra-sens, biphasic, } \\
\text { 70-130 Hz), while active }\end{array}$ & sham & $6 / 10$ & $1-$ \\
\hline $\begin{array}{l}\text { Peurala, } \\
2002\end{array}$ & chronic $(+-3,3 y) ; N=19$ & $\begin{array}{l}\mathrm{SC}+3 \mathrm{w} \text { CES via sock-electrode } \\
\text { (sub-sens, monophasic, } 50 \mathrm{~Hz} \text { ) } \\
2 \times 20 \mathrm{~min}\end{array}$ & & $4 / 6^{*}$ & $2+$ \\
\hline $\begin{array}{l}\text { Yavuzer, } \\
2007\end{array}$ & $\begin{array}{l}\text { subacute }(+-3,5 \mathrm{~m}) ; \mathrm{BS}<4, \\
\text { stand independently; } \mathrm{N}=30\end{array}$ & $\begin{array}{l}\mathrm{SC}+4 \mathrm{w} \text { CES to } \mathrm{n} \text {. peronealis } \\
\text { (supra-sens, biphasic, } 35 \mathrm{~Hz} \text { ) } \\
\text { 30min, } 5 \mathrm{x} / \mathrm{w}\end{array}$ & $\mathrm{SC}$ & $7 / 10$ & $1-$ \\
\hline $\begin{array}{l}\text { Kim, } \\
2015 \mathrm{a}\end{array}$ & $\begin{array}{l}\text { chronic; } \mathrm{N}=12 \text { ( } 6 \text { walker, } 6 \\
\text { non-walker) }\end{array}$ & $\begin{array}{l}\text { single session foot activation } \\
\text { 30min }\end{array}$ & & $3 / 6^{*}$ & 2- \\
\hline $\begin{array}{l}\text { Kim, } \\
2015 b\end{array}$ & chronic $(>1 \mathrm{y}) ; \mathrm{N}=30$ & $8 \mathrm{w}$ foot activation $30 \mathrm{~min}, 3 \mathrm{x} / \mathrm{w}$ & & $3 / 6^{*}$ & $2-$ \\
\hline $\begin{array}{l}\text { Goliwas, } \\
2015\end{array}$ & $\begin{array}{l}\text { chronic }(>12 \mathrm{~m}) ; \text { standing } \\
\text { independently }>30 \mathrm{sec} ; \mathrm{N}=20\end{array}$ & $\begin{array}{l}\mathrm{SC}+6 \mathrm{w} \text { sensorimotor foot } \\
\text { stimulation } 15 \mathrm{~min} 5 \mathrm{x} / \mathrm{w}\end{array}$ & $\mathrm{SC}$ & $6 / 10$ & $1-$ \\
\hline $\begin{array}{l}\text { Lynch, } \\
2007\end{array}$ & $\begin{array}{l}\text { acute }(+-50 \mathrm{~d}), \mathrm{SS} \text { loss; walk } \\
10 \mathrm{~m} \text { assisted; } \mathrm{N}=21\end{array}$ & $\begin{array}{l}\mathrm{SC}+2 \mathrm{w} \text { retraining program } \\
30 \mathrm{~min} 5 \mathrm{x} / \text { week }\end{array}$ & $\mathrm{SC}+$ relaxation & $6 / 10$ & $1-$ \\
\hline $\begin{array}{l}\text { Morioka, } \\
2003\end{array}$ & $\begin{array}{l}\text { subacute }(+-64 d) \text {, standing } \\
\text { independently; } N=26\end{array}$ & $\begin{array}{l}\mathrm{SC}+2 \mathrm{w} \text { hardness discrimination } \\
\text { task } 5 \mathrm{x} / \mathrm{w}\end{array}$ & $\mathrm{SC}$ & $6 / 10$ & $1-$ \\
\hline
\end{tabular}

WBV, whole body vibration; SC, standard care; BBS, Berg balance scale; BS, Brunnstrom stage; FAC, functional ambulation classification; CES, cutaneous electrical stimulation; SS, somatosensory; y, years; m, months; w, weeks; d. davs 
table 4: observed effects of included studies

\begin{tabular}{|c|c|c|c|c|c|c|}
\hline intervention & outcome measure & $\begin{array}{l}\text { gain-EXP } \\
(95 \% \mathrm{CI})\end{array}$ & $\begin{array}{l}\text { time effect } \\
\text { ( } p \text { value) }\end{array}$ & $\begin{array}{l}\text { gain- } \\
\text { CTL }\end{array}$ & $\begin{array}{c}\text { Diff } \\
(95 \% \mathrm{CI})\end{array}$ & interactioneffect ( $\mathrm{p}$ value) \\
\hline \multicolumn{7}{|c|}{ I. somatosensory recovery } \\
\hline \multicolumn{7}{|c|}{$\begin{array}{l}\text { - during or directly after } \\
\text { stimulation }\end{array}$} \\
\hline \multirow[t]{2}{*}{ ES (Tyson) } & $\begin{array}{l}\text { joint position sense - DF } \\
\text { (degree) }\end{array}$ & $\begin{array}{c}+1,8(0.19 \\
3.16)\end{array}$ & $0.029 *$ & & & \\
\hline & $\sim \mathrm{PF}$ & $\begin{array}{c}+1.67(- \\
0.22,3.82)\end{array}$ & 0.078 & & & \\
\hline \multirow[t]{3}{*}{ SMS (Kim.a) } & $\begin{array}{l}\text { monofilament - 5th toe } \\
\text { (thickness) }\end{array}$ & -0.95 & $<0.05^{*}$ & & & \\
\hline & $\sim 1$ st toe & -0.23 & $>0.05$ & & & \\
\hline & $\sim$ dorsal & +0.03 & $>0.05$ & & & \\
\hline \multicolumn{7}{|c|}{$\begin{array}{l}\text { - after repetitive stimulation } \\
\text { sessions }\end{array}$} \\
\hline WBV (Van Nes 06) & monofilament (thickness) & -0.25 & $<0.05^{*}$ & $-2,32$ & & $>0.05$ \\
\hline \multirow[t]{2}{*}{ ES (Peurala) } & VAS & +1.3 & $>0.05$ & & & \\
\hline & SEPs & $\mathrm{n} / \mathrm{r}$ & $<0.05^{*}$ & & & \\
\hline \multirow[t]{4}{*}{ SRe (Lynch) } & $\begin{array}{l}\text { monofilament test - heel } \\
\text { (thickness) }\end{array}$ & $\mathrm{n} / \mathrm{r}$ & $0.026^{*}$ & $\mathrm{n} / \mathrm{r}$ & & $>0.05$ \\
\hline & $\sim$ lateral border & $\mathrm{n} / \mathrm{r}$ & $0.024 *$ & $\mathrm{n} / \mathrm{r}$ & & $>0.05$ \\
\hline & $\sim 1$ st toe & $\mathrm{n} / \mathrm{r}$ & $0.011 *$ & $\mathrm{n} / \mathrm{r}$ & & $>0.05$ \\
\hline & distal proprioception test & $\mathrm{n} / \mathrm{r}$ & 0.55 & $\mathrm{n} / \mathrm{r}$ & & 0.057 \\
\hline \multirow[t]{3}{*}{ SMS (Kim.b) } & $\begin{array}{l}\text { monofilament- 5th toe } \\
\text { (thickness) }\end{array}$ & $-1,14$ & $<0.01 *$ & & & \\
\hline & $\sim 1$ st toe & $-1,12$ & $<0.01 *$ & & & \\
\hline & $\sim$ dorsal & -1.11 & $<0.01 *$ & & & \\
\hline \multicolumn{7}{|c|}{$\begin{array}{l}\text { IIa. immediate carry-over effect } \\
\text { on ... }\end{array}$} \\
\hline \multicolumn{7}{|l|}{ - balance } \\
\hline WBV (Chan) & $\begin{array}{l}\text { weight distribution } \\
\text { symmetry }\end{array}$ & +3.47 & & +0.2 & $\begin{array}{l}-3.27(- \\
6.02,- \\
0.51)\end{array}$ & $0.022 *$ \\
\hline \multirow[t]{2}{*}{ WBV (Van Nes 04) } & postural sway EC & $\mathrm{n} / \mathrm{r}$ & $0.009 *$ & & & \\
\hline & $\begin{array}{l}\text { weight distribution } \\
\text { symmetry }\end{array}$ & $\mathrm{n} / \mathrm{r}$ & $0.027^{*}$ & & & \\
\hline ES (Tyson) & forward reach $(\mathrm{cm})$ & +4.16 & $0.009 *$ & & & \\
\hline SMS (Kim.a) & BBS & $+5,25$ & $<0.05^{*}$ & & & \\
\hline SMS (Kim.b) & TIS - static & -0.19 & $>0.05$ & & & \\
\hline
\end{tabular}




\begin{tabular}{|c|c|c|c|c|c|c|}
\hline & $\sim$ dynamic & +1.87 & $<0.01 *$ & & & \\
\hline & $\sim$ coordination & +0.56 & $>0.05$ & & & \\
\hline \multicolumn{7}{|l|}{ - mobility } \\
\hline \multirow[t]{2}{*}{ WBV (Chan) } & TUG & -6.48 & & -0.45 & $\begin{array}{l}6.03 \\
(3.17 \\
8.89)\end{array}$ & 0.0003* \\
\hline & $10 \mathrm{MWT}$ & -2.09 & & -0.10 & $\begin{array}{r}1.99 \\
(0.11 \\
3.87)\end{array}$ & $0.039^{*}$ \\
\hline LV (Kawahira) & gait speed $(\mathrm{m} / \mathrm{s})$ & +0.05 & $<0.01 *$ & & & \\
\hline \multirow[t]{2}{*}{ ES (Walker) } & foot placement - ML & & $0.006^{*}$ & & & \\
\hline & $\sim \mathrm{AP}$ & & $>0.05$ & & & \\
\hline ES (Tyson) & gait speed $(\mathrm{m} / \mathrm{s})$ & +0.03 & $0.002 *$ & & & \\
\hline \multicolumn{7}{|c|}{ IIb. long term carry-over effect } \\
\hline \multicolumn{7}{|l|}{ - on balance } \\
\hline \multirow[t]{2}{*}{ WBV (Van Nes 06) } & BBS & +16.7 & $<0.01 *$ & +17.4 & -0.7 & $>0.05$ \\
\hline & TCT & +5.5 & $<0.01 *$ & +10.5 & -5.0 & $>0.05$ \\
\hline \multirow[t]{2}{*}{ TS (Chen) } & PASS-TC & +5.0 & $<0.001 *$ & +5.0 & +-0 & 0.597 \\
\hline & BBS & +28.0 & $<0.001 *$ & +15.5 & +7.5 & $0.007 *$ \\
\hline TS (Liang) & BBS & +30.3 & $<0.05^{*}$ & +21 & +9.3 & 0.050 \\
\hline TS (Hsu) & PASS & +1.1 & $>0.05$ & +0.2 & +0.9 & 0.206 \\
\hline \multirow[t]{3}{*}{ SMS (Kim.b) } & TIS - static & +0.22 & $>0.05$ & & & \\
\hline & $\sim$ dynamic & +3.07 & $<0.01$ & & & \\
\hline & $\sim$ coordination & +1.14 & $<0.01$ & & & \\
\hline \multirow[t]{2}{*}{ SMS (Goliwas) } & $\begin{array}{l}\text { weight distribution } \\
\text { symmetry EO }\end{array}$ & $+12.2 \%$ & $<0.05$ & $+2.4 \%$ & $+9.8 \%$ & $<0.05^{*}$ \\
\hline & $\sim \mathrm{EC}$ & $+8.1 \%$ & $<0.05$ & $+2.4 \%$ & $+6.7 \%$ & $>0.05$ \\
\hline SRe (Lynch) & BBS & $+5,1$ & $<0.005$ & $+3,81$ & $\begin{array}{c}+1.29(- \\
3.16 \\
5.74)\end{array}$ & $>0.05$ \\
\hline \multirow[t]{2}{*}{ SRe (Morioka) } & postural sway EO & -11.6 & $<0.01$ & -1.7 & +9.9 & $<0.05^{*}$ \\
\hline & $\sim \mathrm{EC}$ & -9.9 & $<0.05$ & -4.6 & +4.3 & $>0.05$ \\
\hline \multicolumn{7}{|l|}{ - on mobility } \\
\hline \multirow[t]{2}{*}{ WBV (Van Nes 06) } & RMI & +3.4 & $<0.01 *$ & +3.6 & -0.2 & $>0.05$ \\
\hline & FAC & +2 & $<0.01 *$ & +2 & +-0 & $>0.05$ \\
\hline \multirow[t]{2}{*}{ LVib (Paoloni) } & $\begin{array}{l}\text { DF angle at heel-contact } \\
\text { (detailed gait analysis in } \\
\text { article) }\end{array}$ & +6.71 & 0.001 & +1.54 & +5.17 & $>0.05$ \\
\hline & gait speed $(\mathrm{m} / \mathrm{s})$ & +0.09 & 0.047 & +0.02 & +0.07 & $>0.05$ \\
\hline TS (Chen) & mMAS & +16.0 & $<0.001 *$ & +10.5 & +6 & $0.010^{*}$ \\
\hline
\end{tabular}




\begin{tabular}{|c|c|c|c|c|c|c|}
\hline & FAC & +2 & $<0.001 *$ & +1 & +1 & $<0.001 *$ \\
\hline \multirow[t]{2}{*}{ TS (Liang) } & mMAS & +18.3 & $<0.05^{*}$ & +11.8 & +6.5 & $<0.05 *$ \\
\hline & FAC & +2.3 & $<0.05^{*}$ & +1.5 & +0.8 & $<0.05^{*}$ \\
\hline \multirow[t]{2}{*}{ TS (Hsu) } & mob-STREAM & +2.8 & $<0.01 *$ & +0.3 & +2.5 & 0.087 \\
\hline & FAC & +0.8 & $<0.01 *$ & +0.4 & +0.4 & 0.177 \\
\hline \multirow[t]{2}{*}{ ES (Peurala) } & 10MWT (s) & -6.3 & $>0.05$ & & & \\
\hline & mMAS & +2.4 & $<0.05^{*}$ & & & \\
\hline \multirow[t]{2}{*}{ ES (Yavuzer) } & $\begin{array}{l}\text { gait kinematics (detailed } \\
\text { gait analysis in article) }\end{array}$ & & $>0.05$ & & & $>0.05$ \\
\hline & gait speed $(\mathrm{m} / \mathrm{s})$ & +0.03 & $>0.05$ & +0.01 & +0.02 & $>0.05$ \\
\hline \multirow[t]{2}{*}{ SRe (Lynch) } & gait speed $(\mathrm{m} / \mathrm{s})$ & $\mathrm{n} / \mathrm{r}$ & $.012 *$ & $\mathrm{n} / \mathrm{r}$ & & 0.337 \\
\hline & ILA & $\mathrm{n} / \mathrm{r}$ & .376 & $\mathrm{n} / \mathrm{r}$ & & 0.114 \\
\hline
\end{tabular}

EXP, experimental; CTL, control; ES, electrical stimulation; DF, dorsalflexion; PF, plantarflexion; SMS, sensorimotor stimulation; WBV, whole body vibration; VAS, visual analogue scale; SEPs, sensory-evoked potentials; n/r, not reported; SRe, sensory retraining; EC, eyes closed condition; BBS, berg balance scale; ES electrical stimulation; LV, local vibration; TIS, trunk impairment scale; TUG, timed up and go test; 10MWT, 10 meter walking test; ML, medio-lateral; antero-posterior; TCT, trunk control test; TS, thermal stimulation; PASS(-TC), postural assessment scale for stroke patients (- trunk control); EO, eyes open condition; RMI, Rivermead mobility index; FAC, functional ambulation classification; mMAS, modified Motor Assessment Scale; ILA, Iowa level of assistance; mob-STREAM, mobility section - Stroke Rehabilitation Assessment of Movement; 